\title{
Effects of Boardroom Tussle on Stock Return of Malaysian Listed Companies
}

\author{
Tee Peck-Ling ${ }^{1}$, Aik Nai-Chiek ${ }^{2}$, Khong Yeen-Lai ${ }^{3}$ \\ 1,2,3Faculty of Accountancy and Management, \\ Universiti Tunku Abdul Rahman, Malaysia \\ teepl@utar.edu.my1, aiknc@utar.edu.my²,khongyl@utar.edu.my ${ }^{3}$ \\ DOI: https://doi.org/10.37134/jcit.vol8.7.2018
}

\begin{abstract}
Due to differences in opinions and goals, disagreement within the board of directors is common in corporate world. Conflicts in the boardrooms can occur not just between groups of shareholders trying to acquire controlling interest in a company, but also between executive and non-executive directors who represent different stakeholders. Reputation damaging effects model predicts that boardroom tussle events have negative influence on stock returns, whilst the concentration of ownership and control that followed after the tussles can reduce agency problem and positively influence stock returns. This research includes all the 30 events of boardroom tussles involving 10 public listed companies over the period from year 2014 to year 2017 that are announced in Bursa Malaysia website as the sample. This research applies paired-sample compare means ttest method with hypothesized mean difference value of zero to determine whether cumulative abnormal return (CAR) is significant over various event windows for boardroom tussles. Results show that CAR is generally positive before the announcement, but become negative thereafter. In addition, CAR of affected companies is significantly negative over the period of five trading days after the event, indicating that the Malaysian stock market might not be semi-strong form efficient. Stock traders can utilise public information on boardroom tussle to sell the shares of affected company and purchase back five trading days later to earn an abnormal profit.
\end{abstract}

Keywords: boardroom tussle; cumulative abnormal return; agency theory; reputation damage; efficient market hypothesis

\section{INTRODUCTION}

Disagreement within the board of directors is unavoidable in the corporate world. Differences in opinions and goals among the directors who represent various stakeholder groups usually caused such disagreement (Fama \& Jensen, 1983). Conflicts in the boardrooms can occur not just between groups of shareholders trying to acquire controlling interest in a company, but also between executive and non-executive directors. Executive directors are more involved in daily operations of the company, whereas independent non-executive directors are more responsible to ensure the adoption of recommended corporate governance best practices laid down in the Malaysian Code on Corporate Governance 2012 (MCCG 2012) as well as to share their experiences and expertise in the formulation of strategic decisions for the company. To ensure separation of powers within a company, paragraph 15.02(1) in Bursa Malaysia Main Market Listing Requirements stated that at least two directors or one-third of the board of directors of a public listed company, whichever higher, must be independent non-executive directors. However, lack of understanding on the purpose and importance of corporate governance best practices in some companies have occasionally lead to suspension or removal of 
independent non-executive directors from performing their duties and even legally sue them for breach of professional conduct stated under Companies Act 2016. The latter could encompass a director makes improper use of any price-sensitive information of the company to gain personal benefits, a director does not disclose his shareholdings in other companies or a director does not disclose his interest in any contract or proposed contract undertaken by the company.

There is a contradiction in regards to the effects of boardroom tussle on stock return between results obtained from past empirical studies and theory. Some previous studies have pointed out that boardroom tussles usually bring bad image towards the company involved and consequently jeopardise its stock return (Liu, Aharony, Richardson, \& Yawson, 2016; Fiordelisi, Soana, \& Schwizer, 2013; Dewally \& Peck, 2010). On the other hand, with of one group of shareholders who try to gain controlling stake in a company by removing another group of shareholders from the board, such boardroom tussle can eventually lead to concentration of ownership and control, hence financial performance of the company involved will no longer be harmed by the separation of ownership and control as predicted by Jensen and Meckling (1976) agency theory. Apart from that, this research aims to fill the gap by providing empirical evidence that have been lacking in Malaysia on how the boardroom tussle events affect share return. Therefore, the null and alternative hypotheses in this research are stated as:

$\mathrm{H}_{0}$ : CAR around the announcement of boardroom tussle equals to zero.

$\mathrm{H}_{1}$ : CAR around the announcement of boardroom tussle not equal to zero.

Results obtained from this research can be used to judge whether the Malaysian stock market is semi-strong form efficient or inefficient, as well as to provide some recommendations to share traders and fund managers on how to benefit from boardroom tussle events when happened.

\section{LITERATURE REVIEW}

Directors are agents entrusted by shareholders to manage the company to fulfil shareholders' expectations. Unlike private companies, public listed companies are governed by more rules and regulations that encourage and recommend separation of ownership and control between principals and agents. Principals are the owners who hire agents to manage their business on behalf (Jensen \& Meckling, 1976). However, it has been shown from real cases in corporate world that some directors tend to maximise their own wealth before fulfilling shareholders' expectations. Due to this conflict of interest between the directors and shareholders, disagreements begin to develop in the company over time. Agency problem in a company can be minimized by having a sound governance system with very clear separation of roles and responsibilities between executive and nonexecutive directors to balance the power in the boardroom (Hsiang-Tsui, 2005).

Poor risk management and fraudulent events that caused financial losses in a company usually lead to suspension of directors from their duties to facilitate investigation. Unhappy suspended directors may in turn refute by suing their company. This boardroom tussle event could eventually bring damaging effects on companies' 
reputation (Fiordelisi et al., 2013) as well as negative stock market reactions (Perry \& de Fontnouvelle, 2005).

Family feud has been identified as one of the reasons for boardroom tussle. Many corporations in East Asia are family-owned businesses. Claessens, Djankov, \& Lang, (2000) revealed that when new generations begin to involve in the management of these familyowned businesses, they might want to implement some new things that change the direction of their businesses, but very often older generations who are still the shareholders or sit in the board of directors might disagree with those new ideas. This could eventually lead to the occurrence of boardroom tussle to gain control on the operational direction of their companies. Rahman and Ali (2006) study in Malaysia also found similar evidence since many of the Chinese-owned companies are family-owned.

On the other hand, Mishra, Randoy and Jensen (2001) concluded that family-owned companies tend to have smaller board size. Smaller boards tend to have less conflict than larger boards. Therefore, even if boardroom tussle took place in family-owned companies with smaller boards, the effects on share prices are insignificant. However, tussle in companies with larger boards have caused significant drop in share prices.

Liu et al., (2016) study in the U.S. found that most boardroom tussles do not end up with mutual consent between conflicting parties in the company and one party will go to the extent of suing the other party in court. Lawsuits triggered by boardroom tussles significantly reduce the market valuation of companies being sued by an amount far exceeding the estimated legal cost, mainly attributed to a decline in company's reputation which is a form of market based penalty, and directors involved could also suffer personal reputation loss (Desai, Hogan, \& Wilkins, 2006). Therefore, these market reactions towards boardroom tussle have a significant negative influence on the company's stock return.

Besides, boardroom tussles often followed by forced departure of some good directors. This might be viewed negatively by the market investors because the lost of monitoring by these good non-executive directors allow the management team to become even more entrenched in exploiting the company's resources for their personal interest (Dewally \& Peck, 2010). Tang, Lin, Peng, Du, \& Chan (2016) also found that share prices of companies in China fall upon the resignation of directors.

\section{METHODOLOGY}

Target population of this study comprises all the 920 companies listed on Bursa Malaysia Main Market and Ace Market as at 31 ${ }^{\text {st }}$ March 2017. With the MCCG revised once again in year 2012 to improve the independence and transparency of directors' duties as well as to reduce potential boardroom conflicts, sampling period for this study has been set to cover the period from year 2014 to year 2017.

For this research, the term "boardroom tussle" can include any of the following: (i) issuance of notice of general meeting relating to removal of director; (ii) announcement on outcome of general meeting on removal of director; (iii) filing of legal actions against the director and/ or shareholder; and (iv) suspension of director. Based on all the announcements listed down in Bursa Malaysia's website, there are 30 events of boardroom tussles involving 10 public listed companies over this sampling period (refer to Table 1). 
Secondary data for each event such as daily opening and closing stock prices, dividend paid on that day (if any) and stock beta are downloaded from the Bloomberg database. Besides, daily opening and closing FTSE Kuala Lumpur Composite Index (KLCI) and riskfree rate of return are also retrieved from the Bloomberg database.

Table 1: List of Boardroom Tussle Events in Malaysia 2014-2017

\begin{tabular}{|c|c|c|c|}
\hline No. & Name of Company & Event as announced by Bursa Malaysia & Date of Event \\
\hline 1. & Appasia Berhad & Issuance of Notice of Removal of Directors & 16.04 .2014 \\
\hline 2. & Appasia Berhad & Issuance of Notice of Removal of Directors & 12.05 .2014 \\
\hline 3. & Anzo Holdings Berhad & Issuance of Notice of Removal of Directors & 10.06 .2014 \\
\hline 4. & Anzo Holdings Berhad & Legal Suit between Directors and Shareholders & 10.06 .2014 \\
\hline 5. & Appasia Berhad & Outcome of Meeting on Removal of Director & 10.06 .2014 \\
\hline 6. & Multi-Usage Holdings Berhad & Issuance of Notice of Removal of Directors & 19.11.2014 \\
\hline 7. & Multi-Usage Holdings Berhad & Legal Suit between Directors and Shareholders & 15.12 .2014 \\
\hline 8. & Multi-Usage Holdings Berhad & Legal Suit between Directors and Shareholders & 15.12 .2014 \\
\hline 9. & Multi-Usage Holdings Berhad & Legal Suit between Directors and Shareholders & 02.07 .2015 \\
\hline 10. & Kronologi Asia Berhad & Issuance of Notice of Removal of Directors & 11.08 .2015 \\
\hline 11. & Wintoni Group Berhad & Issuance of Notice of Removal of Directors & 13.08 .2015 \\
\hline 12. & Wintoni Group Berhad & Outcome of Meeting on Removal of Director & 11.09 .2015 \\
\hline 13. & Scan Associates Berhad & Legal Suit between Directors & 17.09.2015 \\
\hline 14. & Wintoni Group Berhad & Legal Suit between Directors and Shareholders & 28.09 .2015 \\
\hline 15. & Wintoni Group Berhad & Legal Suit between Directors and Shareholders & 28.09 .2015 \\
\hline 16. & Multi-Usage Holdings Berhad & Legal Suit between Directors and Shareholders & 12.04 .2016 \\
\hline 17. & Advance Information Marketing Berhad & Issuance of Notice of Removal of Directors & 21.04 .2016 \\
\hline 18. & Advance Information Marketing Berhad & Outcome of Meeting on Removal of Director & 24.05 .2016 \\
\hline 19. & Multi-Usage Holdings Berhad & Legal Suit between Directors and Shareholders & 16.06 .2016 \\
\hline 20. & Multi-Usage Holdings Berhad & Legal Suit between Directors and Shareholders & 09.08 .2016 \\
\hline 21. & Multi-Usage Holdings Berhad & Legal Suit between Directors and Shareholders & 06.09 .2016 \\
\hline 22. & YFG Berhad & Issuance of Notice of Removal of Directors & 14.09 .2016 \\
\hline 23. & YFG Berhad & Outcome of Meeting on Removal of Directors & 29.09 .2016 \\
\hline 24. & PDZ Holdings Berhad & Issuance of Notice of Removal of Directors & 28.11 .2016 \\
\hline 25. & Multi-Usage Holdings Berhad & Suspension of Directors & 28.11 .2016 \\
\hline 26. & Multi-Usage Holdings Berhad & Legal Suit between Directors & 13.12 .2016 \\
\hline 27. & Multi-Usage Holdings Berhad & Legal Suit between Directors & 16.01 .2017 \\
\hline 28. & Multi-Usage Holdings Berhad & Lodgment of Police Report against Director & 20.01 .2017 \\
\hline 29. & EKA Noodles Berhad & Issuance of Notice of Removal of Directors & 20.01 .2017 \\
\hline 30. & Multi-Usage Holdings Berhad & Legal Suit between Directors & 16.02 .2017 \\
\hline
\end{tabular}

Source: Bursa Malaysia Securities Berhad, Company Announcements. Retrieved from http://www.bursamalaysia.com/market.

Abnormal return is the difference between the actual return of a stock and its riskadjusted required rate of return derived from the Capital Asset Pricing Model (CAPM). Existence of abnormal return indicates that the occurrence of an event may contain some information of that company which have not yet priced by investors in the stock market. Positive (negative) abnormal return shows that the occurrence of boardroom tussle event has brought positive (negative) influences on the company's stock price. This study adopts market model applied in Mitchell and Netter (1997) and Gatzert (2015), where daily actual return, required return and abnormal return of a stock are calculated as follow:

Daily actual return $\mathrm{f}=\left[\left(\right.\right.$ Closing price $_{t}-$ Opening price $\left.t\right) /$ Opening price $\left.t\right] \times 100 \%$

Daily required return $_{t}=\{$ Risk-free return $t+$

$$
\text { [Beta X (KLCI return } t \text { - Risk-free returnt })]\} \text { X 100\% }
$$

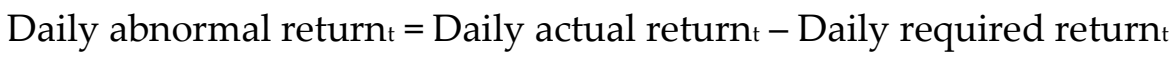


In this study, daily abnormal returns calculation over event windows of -1 to +1 trading day, -3 to +3 trading days and -5 to +5 trading days are triggered by occurrences of boardroom tussle among Malaysian public listed companies. Then, cumulative abnormal return (CAR) of the company's stock in each boardroom tussle event will be computed by summing up the daily abnormal returns over each of the respective event windows. CAR is applied instead of compounding daily abnormal returns because the latter can create bias in the results (Brown \& Jerold, 1985; Williams \& Siegel, 1997). CAR for the 30 identified boardroom tussle events are shown in Table 2.

Table 2: Cumulative Abnormal Return (CAR) for Boardroom Tussle Events in Malaysia

\begin{tabular}{|c|c|c|c|c|c|c|c|}
\hline \multirow[t]{2}{*}{ No. } & \multirow[t]{2}{*}{ Name of Company } & \multicolumn{6}{|c|}{$\begin{array}{c}\text { Cumulative Abnormal Return (CAR) in \% } \\
\text { By Event Windows (days) }\end{array}$} \\
\hline & & $t-1$ & $t+1$ & $t-3$ & $\mathrm{~T}+3$ & $t-5$ & $t+5$ \\
\hline 1 & APP & $-10.55 \%$ & $1.41 \%$ & $-1.46 \%$ & $-2.51 \%$ & $-1.46 \%$ & $-1.10 \%$ \\
\hline 2 & APP & $-4.83 \%$ & $-4.37 \%$ & $0.13 \%$ & $0.40 \%$ & $5.35 \%$ & $0.13 \%$ \\
\hline 3 & ANZO & $1.95 \%$ & $-2.67 \%$ & $1.47 \%$ & $-1.50 \%$ & $7.31 \%$ & $-1.55 \%$ \\
\hline 4 & ANZO & $1.95 \%$ & $-2.67 \%$ & $1.47 \%$ & $-1.50 \%$ & $7.31 \%$ & $-1.55 \%$ \\
\hline 5 & ANZO & $0.13 \%$ & $-0.41 \%$ & $0.54 \%$ & $5.66 \%$ & $1.21 \%$ & $0.43 \%$ \\
\hline 6 & MUH & $3.22 \%$ & $-1.85 \%$ & $-0.77 \%$ & $4.18 \%$ & $-3.49 \%$ & $-1.37 \%$ \\
\hline 7 & MUH & $0.46 \%$ & $0.67 \%$ & $3.80 \%$ & $13.20 \%$ & $0.28 \%$ & $-1.53 \%$ \\
\hline 8 & MUH & $0.46 \%$ & $0.67 \%$ & $3.80 \%$ & $13.20 \%$ & $0.28 \%$ & $-1.53 \%$ \\
\hline 9 & MUH & $-2.00 \%$ & $1.81 \%$ & $0.70 \%$ & $-1.97 \%$ & $-2.73 \%$ & $2.96 \%$ \\
\hline 10 & $\mathrm{KAB}$ & $4.41 \%$ & $-7.58 \%$ & $4.70 \%$ & $-1.24 \%$ & $-1.47 \%$ & $-1.18 \%$ \\
\hline 11 & WGB & $-10.16 \%$ & $-1.47 \%$ & $0.12 \%$ & $-0.59 \%$ & $-2.44 \%$ & $0.80 \%$ \\
\hline 12 & WGB & $10.43 \%$ & $-13.56 \%$ & $-0.21 \%$ & $-4.42 \%$ & $2.37 \%$ & $4.57 \%$ \\
\hline 13 & SCAN & $-1.22 \%$ & $6.18 \%$ & $1.56 \%$ & $0.56 \%$ & $-2.62 \%$ & $-0.34 \%$ \\
\hline 14 & WGB & $4.02 \%$ & $-9.11 \%$ & $-2.67 \%$ & $-5.17 \%$ & $10.40 \%$ & $-1.48 \%$ \\
\hline 15 & WGB & $4.02 \%$ & $-9.11 \%$ & $-14.21 \%$ & $-5.17 \%$ & $10.40 \%$ & $-4.64 \%$ \\
\hline 16 & MUH & $2.89 \%$ & $2.85 \%$ & $-0.34 \%$ & $-0.05 \%$ & $1.00 \%$ & $4.27 \%$ \\
\hline 17 & AIM & $0.46 \%$ & $1.30 \%$ & $1.97 \%$ & $4.25 \%$ & $-0.18 \%$ & $-9.60 \%$ \\
\hline 18 & AIM & $0.26 \%$ & $5.53 \%$ & $0.30 \%$ & $25.26 \%$ & $0.24 \%$ & $0.31 \%$ \\
\hline 19 & MUH & $-0.03 \%$ & $-0.83 \%$ & $3.07 \%$ & $-0.10 \%$ & $4.18 \%$ & $0.32 \%$ \\
\hline 20 & MUH & $0.38 \%$ & $1.85 \%$ & $0.40 \%$ & $0.42 \%$ & $0.53 \%$ & $0.37 \%$ \\
\hline 21 & MUH & $-1.21 \%$ & $5.02 \%$ & $0.46 \%$ & $0.42 \%$ & $0.37 \%$ & $0.58 \%$ \\
\hline 22 & YFG & $-0.66 \%$ & $-0.65 \%$ & $-0.84 \%$ & $-0.87 \%$ & $-1.00 \%$ & $-0.98 \%$ \\
\hline 23 & YFG & $-0.18 \%$ & $2.72 \%$ & $0.39 \%$ & $-0.69 \%$ & $-3.87 \%$ & $0.33 \%$ \\
\hline 24 & PDZ & $0.30 \%$ & $1.30 \%$ & $0.46 \%$ & $-0.03 \%$ & $0.28 \%$ & $0.85 \%$ \\
\hline 25 & MUH & $-0.17 \%$ & $-4.52 \%$ & $-0.12 \%$ & $6.28 \%$ & $-0.18 \%$ & $1.56 \%$ \\
\hline 26 & MUH & $-1.45 \%$ & $13.34 \%$ & $6.02 \%$ & $0.02 \%$ & $1.71 \%$ & $-10.22 \%$ \\
\hline 27 & MUH & $0.54 \%$ & $-0.81 \%$ & $-5.88 \%$ & $-0.85 \%$ & $0.50 \%$ & $-10.09 \%$ \\
\hline 28 & MUH & $-0.68 \%$ & $-9.62 \%$ & $-0.68 \%$ & $0.82 \%$ & $0.56 \%$ & $-0.78 \%$ \\
\hline 29 & EKA & $-2.43 \%$ & $-17.52 \%$ & $-2.43 \%$ & $-2.59 \%$ & $-2.17 \%$ & $-16.42 \%$ \\
\hline 30 & MUH & $0.25 \%$ & $9.00 \%$ & $0.25 \%$ & $3.44 \%$ & $0.25 \%$ & $-3.52 \%$ \\
\hline
\end{tabular}

To test whether CAR over a given event window is significantly different from zero, this research uses paired-sample compare means t-test method with hypothesized mean difference value of zero. If the p-value is less than 0.05 , there is enough evidence to reject the null hypothesis which indicates that boardroom tussles have significant influences on stock returns. Positive or negative significant influences will then be determined from the sign of differences in means. Paired-sample compare means t-test will be run for different event windows of -1 to +1 trading day, -3 to +3 trading days and -5 to +5 trading days. 


\section{FINDINGS}

Table 3 shows that mean CAR are generally positive before the announcement of boardroom tussle events, but become negative after the announcement. This result coincides with reputation damaging events model developed by Gatzert (2015) and previous findings in Fiordelisi et al (2013). Boardroom tussle is a reputation damaging event that could result in; (i) customers' perception of the firm, therefore damage the future revenue and operating cash flows; (ii) higher contracting and negotiation costs imposed by the suppliers and business partners in view of damaged reputation of the firm; (iii) departure of employees of the firm; and (iv) investors' caution.

Table 3: Descriptive Statistics of Cumulative Abnormal Return (CAR) for Boardroom Tussle

\begin{tabular}{|l|l|l|l|l|l|l|}
\hline $\begin{array}{l}\text { Event } \\
\text { Window } \\
\text { days) }\end{array}$ & $\begin{array}{l}\text { CAR } \\
\mathbf{t}-\mathbf{1}\end{array}$ & $\begin{array}{l}\text { CAR } \\
\mathbf{t + 1}\end{array}$ & $\begin{array}{l}\text { CAR } \\
\mathbf{t}-\mathbf{3}\end{array}$ & $\begin{array}{l}\text { CAR } \\
\mathbf{t}+\mathbf{3}\end{array}$ & $\begin{array}{l}\text { CAR } \\
\mathbf{t}-5\end{array}$ & $\begin{array}{l}\text { CAR } \\
\mathbf{t}+5\end{array}$ \\
\hline Mean & $0.0187 \%$ & $-1.1033 \%$ & $0.0667 \%$ & $-1.6287 \%$ & $1.0973 \%$ & $-1.6800 \%$ \\
\hline $\begin{array}{l}\text { Standard } \\
\text { Deviation }\end{array}$ & $3.9038 \%$ & $6.4674 \%$ & $3.5352 \%$ & $6.2299 \%$ & $3.7278 \%$ & $4.5020 \%$ \\
\hline Kurtosis & 3.3585 & 0.8582 & 4.9133 & 2.6696 & 1.1041 & 1.3857 \\
\hline Skewness & -0.6004 & -0.4344 & -0.2609 & 0.3370 & 0.8421 & -0.9291 \\
\hline
\end{tabular}

Cumulative gains five trading days before boardroom tussles are higher at 1.0973\% on average compared to three trading days or one trading day before those events. On the other hand, cumulative losses five trading days after boardroom tussles are higher at $1.6800 \%$ on average compared to three trading days or one trading day after those occurrences. If a market investor has accessed to publicly available information in regards to boardroom tussle in a particular company sells or short-sells its stocks and then purchases them back five trading days later, the investor can pocket $1.68 \%$ windfall gain.

CAR measures are generally normally distributed regardless of event windows. As summarized in Table 3, all the skewness scores are below 1.00 in either direction. However, kurtosis scores are slightly out of range for event windows of $t+1, t-1$ and $t-3$.

Table 4: Paired-Sample Compare Means T-Test Results

\begin{tabular}{|l|l|l|l|l|l|l|}
\hline $\begin{array}{l}\text { Event } \\
\text { Window } \\
\text { (days) }\end{array}$ & $\begin{array}{l}\text { CAR } \\
\mathbf{t}-\mathbf{C}\end{array}$ & $\begin{array}{l}\text { CAR } \\
\mathbf{t}+\mathbf{1}\end{array}$ & $\begin{array}{l}\text { CAR } \\
\mathbf{t}-\mathbf{3}\end{array}$ & $\begin{array}{l}\text { CAR } \\
\mathbf{t}+\mathbf{3}\end{array}$ & $\begin{array}{l}\text { CAR } \\
\mathbf{t}-5\end{array}$ \\
\hline $\begin{array}{l}\text { Mean } \\
\text { Difference }\end{array}$ & $0.0187 \%$ & $-1.1033 \%$ & $0.0667 \%$ & $*$ & $* 1.0973 \%$ & \\
\hline t-statistic & 0.0262 & -0.9344 & 0.1033 & -1.4189 & 1.6123 & $-1.6800 \%$ \\
\hline p-value & 0.4896 & 0.1789 & 0.4592 & 0.0814 & 0.0589 & -2.0439 \\
\hline
\end{tabular}

Table 4 summarizes the results from paired-sample compare means t-test. Results reveal that there is enough evidence at 0.05 level to reject the null hypothesis of CAR equals to zero for the period of five trading days after boardroom tussles have become publicly known. Stock prices of those affected companies fall by $1.6800 \%$ on average over that period. Apart from that, there is also slightly significant evidence at 0.10 level to reject the null hypothesis, in which stock prices of those affected companies tumble by $1.6287 \%$ on 
average three trading days after being publicly aware. These evidences contradict with the semi-strong form efficient market hypothesis. According to semi-strong form market efficiency, stock price is supposed to adjust instantaneously on the day when boardroom tussle in a particular company becomes publicly available information, and at such abnormal returns should not be earned by any investor who trades this company's stocks thereafter.

In addition, there is also slightly significant evidence at 0.10 level to point out that insiders of a company with boardroom tussle can earn CAR of $1.0973 \%$ on average if they buy the shares from the market five days before the news is disseminated to the public and later offload the shares in the market on the day when the news is finally publicly available information. This evidence violates the strong-form efficient market hypothesis, in which any investor possesses of insider information in regards to a company's boardroom conflict should not enjoy abnormal gain by trading its shares before the public announcement.

\section{CONCLUSION}

With CAR become negative (losses) after the occurrence of boardroom tussles, owners and their elected directors should understand clearly the roles and responsibilities of each other as well as accept different opinions and views with open minds. Boardroom tussle events generally create bad impression and image as well as loss of confidence towards the affected companies among investors in the stock market. Negative CAR arising from a company's boardroom conflict will harm the stock return and reduce the wealth of both its major and minority shareholders. Battle for corporate control between groups of major shareholders within a company should be minimised because it will eventually lead to a lose-lose situation for all of them when the company's stock price tumbled. Notwithstanding, with the main objective to obtain controlling stake in the company, most rivalry groups of major shareholders have seemingly chosen to ignore this potential negative effect at least for that period in time.

Listed companies in Malaysia should also consider to have an optimal board size since larger board size than optimal might actually increase the possibility of more conflict within the board and subsequently lead to significant fall in share return (Mishra et al, 2001).

With the stock market proven to be inefficient in regards to the announcement of boardroom tussles, day traders in Bursa Malaysia Stock Exchange can take advantage from such market inefficiency to reap abnormal returns. With CAR measures significantly negative three and five trading days after the announcement, day traders should sell or short-sell the shares of subject companies on the announcement day and then buy the shares back three or five days later. Fund managers can also incorporate this trading strategy as one of the ways to generate better yields for their mutual fund investors. 


\section{REFERENCES}

Brown, S., \& Jerold, W. (1985). Using daily stock returns: the case of event studies. Journal of Financial Economics, 14, 3-31.

Claessens, S., Djankov, S., \& Lang, L. H. P. (2000). The separation of ownership and control in East Asian corporations, Journal of Financial Economics, 58, 81-112.

Desai, H., Hogan, C. E., \& Wilkins, M. S. (2006). The reputational penalty for aggressive accounting: Earnings restatements and management turnover. Accounting Review. http://doi.org/10.2308/accr.2006.81.1.83

Dewally, M., \& Peck, S. W. (2010). Upheaval in the boardroom: Outside director public resignations, motivations, and consequences. Journal of Corporate Finance, 16(1), 38- 52.

Fama, E. F. \& Jensen, M. C. (1983). Agency problems and residual claims. Journal of Law and Economics, 26(2), 327-349.

Fiordelisi, F., Soana, M.G., \& Schwizer, P. (2013). The determinants of reputational risk in the banking sector. Journal of Banking \& Finance, 37(5), 1359-1371.

Gatzert, N. (2015). The impact of corporate reputation and reputation damaging events on financial performance: Empirical evidence from the literature. European Management Journal, 33(6), 485-499.

Hsiang-Tsui, C. (2005). An empirical study of corporate governance and corporate performance. The Journal of American Academy of Business Cambridge, 95-101.

Jensen, M. C., \& Meckling, W. H. (1976). Theory of the business: Managerial behavior, agency costs and ownership structure. Journal of Financial Economics, 13, 305-360.

Liu, C., Aharony, J., Richardson, G., \& Yawson, A. (2016). Corporate litigation and changes in CEO reputation: Guidance from U.S. Federal Court lawsuits. Journal of Contemporary Accounting and Economics, 12(1), 15-34.

Mishra, C. S., Randoy, T., \& Jensen, J. I. (2001). The effect of family influence on firm value and corporate governance. Journal of International Financial Management and Accounting, 12(3), 235-259.

Mitchell, M., \& Netter, J. (1997). Finance event studies are used to assess damages. Journal of Economic Literature, 13-39.

Perry, J. \& de Fontnouvelle, P. (2005). Measuring reputational risk: The market reaction to operational loss announcements. Working Paper. Boston, MA: Federal Reserve Bank of Boston.

Rahman, A. R., \& Ali, M. F. H. (2006). Board, audit committee, culture and earning management: Malaysian evidence. Managerial Auditing Journal, 21(7), 783-804.

Tang, X., Lin, Y., Peng, Q., Du, J., \& Chan, K. C. (2016). Politically connected directors and firm value: Evidence from forced resignations in China. The North American Journal of Economics and Finance, 37, 148-167.

Williams, A., \& Siegel, D. (1997). Event studies in management research: Theoretical and empirical issues. Academy of Management Journal, 40(3). 